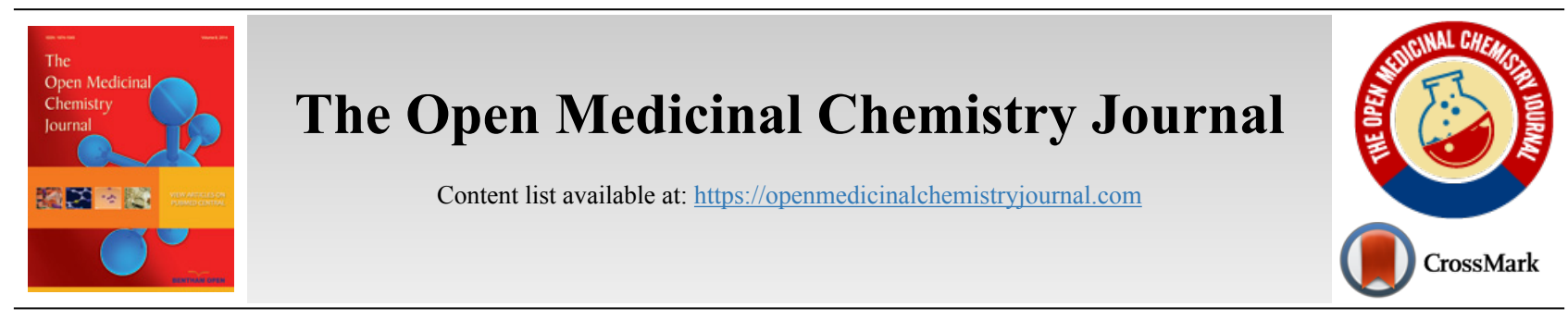

RESEARCH ARTICLE

\title{
Hexacyclododecylamines with Sigma-1 Receptor Affinity and Calcium Channel Modulating Ability
}

\author{
Jacques Joubert ${ }^{1}$, Natasha Strydom ${ }^{1}$, Werner J. Geldenhuys ${ }^{2}$, Yolande Greyling ${ }^{3}$, Sandra V. Dyk ${ }^{3}$ and Sarel F. Malan ${ }^{1, *}$ \\ ${ }^{1}$ Pharmaceutical Chemistry, School of Pharmacy, University of the Western Cape, Private Bag X17, Bellville, South Africa \\ ${ }^{2}$ Department of Pharmaceutical Sciences, West Virginia University, School of Pharmacy, Morgantown WV, USA \\ ${ }^{3}$ Pharmaceutical Chemistry, School of Pharmacy, North-West University, Private Bag X6001, Potchefstroom, South Africa
}

\begin{abstract}
:
Introduction:

Recent research points to the Sigma Receptor $(\sigma \mathrm{R})$ as a possible neuromodulatory system with multi-functional action and $\sigma_{1}$ Rs have been suggested as a drug target for a number of CNS conditions. Hexacyclododecylamines have shown $\sigma_{1} \mathrm{R}$ activity and provide an advantageous scaffold for drug design that can improve the blood-brain barrier permeability of privileged structures.
\end{abstract}

\section{Methods and Materials:}

A series of oxa- and aza- hexaxcyclododecylamines were synthesised and evaluated for sigma-1 receptor activity and voltage-gated calcium channel blocking ability to determine the effect of inclusion of amine containing heterocycles.

\section{Results \& Discussion:}

The compounds had promising $\sigma_{1} \mathrm{R}$ activities $(\mathrm{K} i=0.067-11.86 \mu \mathrm{M})$ with the aza-hexacyclododecylamines $\mathbf{1 2}, \mathbf{2 4}$ and 27 showing some of the highest affinities $(\mathrm{K} i=0.067 \mu \mathrm{M}, 0.215 \mu \mathrm{M}$ and $0.496 \mu \mathrm{M}$ respectively). This confirms, as observed in previous studies, that the aza compounds are more favourable for $\sigma_{1} \mathrm{R}$ binding than their oxa counterparts. The addition of the amine heterocycle showed affinities similar to that of related structures with only two lipophilic binding regions. This indicates that the inclusion of an amine heterocycle into these structures is a viable option in the design of new $\sigma_{1} \mathrm{R}$ ligands. Significant voltage-gated calcium channel blocking ability was also observed for 12, 24 and $\mathbf{2 7}$, suggesting a link between $\sigma_{1} R$ activity and intracellular calcium levels.

Conclusion:

The $\sigma_{1} \mathrm{R}$ activity and potential effect on other receptor classes and calcium channels could prove beneficial in pharmacological application.

Keywords: Hexacyclododecylamines, Sigma-1 receptor, Voltage-gated calcium channels, Neuromodulatory, Calcium levels, Pharmacological application.

\begin{tabular}{|l|l|l|r|}
\hline Article History & Received: November 13, 2018 & Revised: January 28, 2019 & Accepted: February 06, 2019 \\
\hline
\end{tabular}

\section{INTRODUCTION}

The sigma receptor, which was originally thought to be an opioid receptor, is divided into two subtypes; the Sigma-1 Receptor $\left(\sigma_{1} R\right)$ and the Sigma-2 Receptor $\left(\sigma_{2} R\right)$ which are now classified as distinct receptors $[1,2]$ and do not share homology with any other known mammalian enzyme or receptor [3 - 5]. The $\sigma_{1} \mathrm{R}$ has been cloned and is implicated in intracellular signalling, synaptic transmission, apoptosis and

* Address correspondence to this author at the School of Pharmacy, University of the Western Cape, Private Bag X17, Bellville 7535, South Africa; Tel: +27 219593190; Fax: +27 219591588; E-mail: sfmalan@uwc.ac.za is able to mediate effects on calcium conductance through Voltage-Gated Calcium Channels (VGCC), $N$-methyl-DAspartate (NMDA) receptor activity, potassium channel activity, protein kinases and modulation of inositol phosphatases [6 - 8]. The $\sigma_{1} \mathrm{R}$ receptor is located on the endoplasmic reticulum and it is likely that the $\sigma_{1} \mathrm{R}$ mediates its response via translocation from the endoplasmic reticulum to other cellular compartments $[9,10]$.

The role of sigma receptors in mediating neuroprotection or neurodegeneration has been studied in several in vitro models of Central Nervous System (CNS) injury [11 - 13]. A 
consistent positive correlation between sigma neuroprotective potency and $\sigma_{1} \mathrm{R}$ binding site affinity has been demonstrated, suggesting that the functional neuroprotective effect of $\sigma \mathrm{R}$ ligands may be mediated by binding at the $\sigma_{1} R$ site [11]. Activation of $\sigma_{1} \mathrm{R}$ receptors results in a complex, bipolar modulation of calcium homeostasis. It facilitates the mobilisation of inositol triphosphate receptor-gated intra-cellular calcium pools at the endoplasmic reticulum level and modulates extracellular calcium influx through VGCC at the plasma membrane level $[12,13]$. Overstimulation of $\sigma_{1}$ receptors may contribute to toxic intracellular calcium concentrations and sigma receptors are thus a target for neuroprotective drugs aimed at calcium modulation [12, 13]. Additionally, the $\sigma_{1} \mathrm{R}$ receptors and the ER play an important functional role with the mitochondria, where the ER-tomitochondria miscommunication has been implicated in calcium exchange and other cellular processes like mitophagy [14].

Since the discovery of $\sigma$ Rs, much research was done in this field due to the implication of these receptors in various major (CNS) diseases $[15,16]$. Some of the earliest $\sigma \mathrm{R}$ ligands identified were diverse clinical antipsychotics that bind to $\sigma_{1} R s$ with nanomolar affinity [17] and several antidepressants from unrelated pharmacological classes that interact with $\sigma_{1}$ Rs with high affinity $[18,19]$. The role of $\sigma_{1} \mathrm{R}$ in Alzheimer's disease [20], Parkinson's disease [20], anxiety disorders [21], depression [22] and drug addiction [23] is well accepted.

Polycyclic amines, such as the hexacyclododecylamine (HCD; also described as pentacycloundecylamines in literature) and the adamantane amines, were shown to be valu-able scaffolds in the development of CNS drugs [24, 25]. These polycyclic compounds possess their own neuromodulatory activity on important receptor classes that have been implicated in CNS disease states such as Alzheimer's disease, Parkinson's disease, Huntington's disease, schizophrenia, stroke and disease states as intricate as drug addiction [24 - 26]. They act as NMDA receptor antagonists $[27,28]$, are able to spontaneously increase dopamine release [29] and have been shown to have neuroprotective activity through modulation of VGCC flux $[28,30]$. Binding studies have confirmed that they also have an affinity for the sigma receptor and that the polycyclic amine group is important for binding interactions [31 - 33]. They further have the ability to greatly improve lipophilicity of their conjugates, which is helpful in increasing blood-brain barrier permeability leading to increased concentration of CNS acting drugs in the brain, decreasing dosage and ultimately minimising peripheral side effects $[34,35]$. Several studies have shown that both HCD containing compounds and the structurally related adamantane moiety may present with sigma receptor activity [31 - 33].

Based on the above observations a series of hexacyclododecylamines were designed and synthesised to evaluate the effect of including an amine-containing heterocyclic group compared to previous (HCD) structures containing only two lipophilic regions (Fig. 1 and Table 1). The inclusion of an amine-containing ring has been shown to improve $\sigma_{1} R$ activity in an array of structurally distinct compounds [36, 37]. This design would, therefore, serve as a preliminary study into the potential of including an amine-containing heterocyclic ring between the two lipophilic regions of these compounds. This may lead to better alignment of the compounds in the $\sigma_{1} R$ and/or additional binding interactions with the $\sigma_{1} R$. In addition, $\sigma_{1} R$ antagonists have shown to regulate $L$-type VGCCs which may affect $\mathrm{Ca}^{2+}$ flux through these channels $[12,13]$. The purpose of this study was thus to evaluate a series of HCD derivatives for modulating effect on the $\sigma_{1} \mathrm{R}$ and intracellular calcium concentrations through VGCCs in an attempt to explore the neuromodulatory potential of this structural class of compounds.

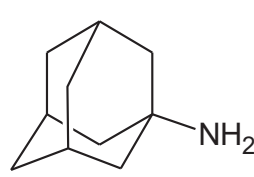

Amantadine

$\mathrm{K}_{l}(\mu \mathrm{M})=7.44$

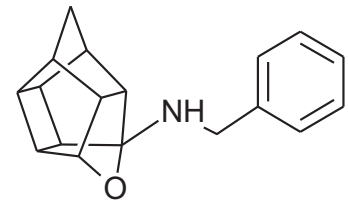

NGP 1-01

$\mathrm{K}_{l}(\mu \mathrm{M})=0.869$

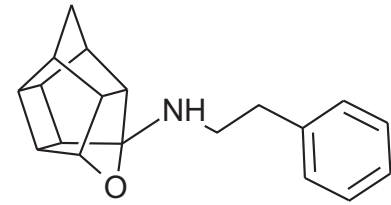

1

$\mathrm{K}_{l}(\mu \mathrm{M})=0.752$

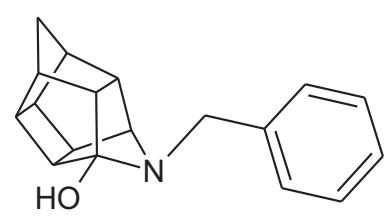

2

$\mathrm{K}_{l}(\mu \mathrm{M})=0.103$

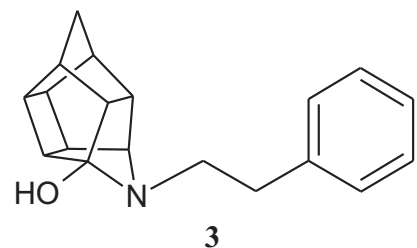

$\mathrm{K}_{l}(\mu \mathrm{M})=0.020$

Fig. (1). Structures of polycyclic amines; amantadine, NGP1-01 and related hexacyclododecylamines 1-3, with affinity for the $\sigma_{1}$ R. 


\section{EXPERIMENTAL SECTION}

\subsection{Chemistry: General Procedures}

Unless otherwise specified, materials were obtained from Sigma Aldrich ${ }^{\circledR}$ and Merck $^{\circledR}$ and used without further purification. All reactions were monitored by thin-layer chromatography on $0.20 \mathrm{~mm}$ thick aluminium silica gel sheets (Alugram $^{\circledR}$ SIL G/UV ${ }_{254}$, Kieselgel 60, Macherey-Nagel, Düren, Germany). Visualisation was achieved using a Chromato-vue ${ }^{\circledR}$ Cabinet under UV light (254 nm and $366 \mathrm{~nm}$ ) or with iodine vapours. Mobile phases were prepared on a volume-to-volume basis. Infra-Red (IR) spectra were recorded on a Perkin Elmer Spectrum 400 spectrometer, fitted with a diamond Attenuated Total Reflectance (ATR) attachment. Mass Spectra (MS) were recorded on an analytical VG 70-70E mass spectrometer using Electron Spray Ionisation (ESI) at 70 eV. ${ }^{1} \mathrm{H}$ and ${ }^{13} \mathrm{C}$ NMR spectra were obtained using a Varian Gemini 200 spectrometer at a frequency of $200 \mathrm{MHz}$ and 50 $\mathrm{MHz}$, respectively or a Bruker Advanced 600 Spectrometer at frequencies of $600 \mathrm{MHz}$ and $150 \mathrm{MHz}$ respectively. Tetramethylsilane (TMS) was used as a point of reference in all NMR experiments. All chemical shifts are reported in parts per million (ppm) relative to the signal from TMS $(\delta=0)$, added to an appropriate deuterated solvent. All chemical shifts are reported in parts per million (ppm), relative to the internal standard. The following abbreviations are used to indicate the multiplicities of the respective signals: $\mathrm{s}$ - singlet; $\mathrm{d}$ - doublet; $\mathrm{dd}$ - doublet of doublets; $\mathrm{t}$ - triplet; $\mathrm{m}$ - multiplet; and AB-q $\mathrm{AB}$ quartet. The multiplicity of the identified carbons was confirmed with DEPT-spectra. Microwave synthesis was performed using a CEM Discover ${ }^{\mathrm{TM}}$ microwave synthesis system. Compounds 6 [38], 8 [39], 9 [40], 13 [41], 15 [30], 21 [42] and 22 [40] were synthesised as previously described and all physical characteristics were similar to that reported in the literature.

\subsection{Synthesis of Compounds}

\subsubsection{5-[2-(4-Benzylpiperazin-1-yl)ethyl]-5-azahexacyclo[5.4. $\left.1.0^{2,6} \cdot 0^{3,10} \cdot 0^{4,8} \cdot 0^{9,12}\right]$ dodecan4-ol (12)}

Pentacyclo $\left[5 \cdot 4 \cdot 0.0^{2,6} \cdot 0^{3,1} 0.0^{5,9}\right]$ undecane-8,11-dione-ethylene acetal $(9,200 \mathrm{mg}, 0.917 \mathrm{mmol})$ and compound $8(200 \mathrm{mg}$, $0.913 \mathrm{mmol}$ ) were dissolved in $5 \mathrm{ml} \mathrm{EtOH}$ and reacted under microwave conditions at a maximum temperature of $100^{\circ} \mathrm{C}$, power setting of $150 \mathrm{~W}$ and pressure of 150 psi for 30 minutes. The reaction mixture was allowed to cool and directly used in the next step. The cooled solution of crude compound $\mathbf{1 0}$ was dissolved in $5 \mathrm{ml} \mathrm{EtOH}$ and $\mathrm{NaBH}_{4}(159 \mathrm{mg}, 4.20 \mathrm{mmol}, 1.4$ equiv.) was added. The mixture was stirred at room temperature for 8 hours where after EtOH was evaporated under reduced pressure, water $(10 \mathrm{ml})$ was added and the mixture was extracted with DCM $(3 \times 10 \mathrm{ml})$. The combined organic extracts were washed with brine $(10 \mathrm{ml})$, dried $\left(\mathrm{Na}_{2} \mathrm{SO}_{4}\right)$, and concentrated in vacuo. To this crude material (11), acetone $(25 \mathrm{ml})$ and $4 \mathrm{M}$ aq. $\mathrm{HCl}(15 \mathrm{ml})$ were added. After stirring at room temperature for $6 \mathrm{~h}$, the mixture was diluted with $\mathrm{H}_{2} \mathrm{O}(200 \mathrm{ml})$, basified to $\mathrm{pH} 14$ with $1 \mathrm{M}$ aq. $\mathrm{NaOH}$, and extracted with DCM $(3 \times 15 \mathrm{ml})$. The combined organic extracts were dried $\left(\mathrm{Na}_{2} \mathrm{SO}_{4}\right)$ and concentrated in vacuo. The crude product was purified by recrystallization from EtOH to yield the desired compound (12) as colourless crystals (Yield $=183 \mathrm{mg}, 53 \%$ ) [38]. Physical data: ${ }^{1} \mathrm{H}$ NMR $\left(200 \mathrm{MHz}, \mathrm{CDCl}_{3}\right) \delta_{\mathrm{H}}: 7.26-7.16(\mathrm{~m}, 5 \mathrm{H}), 3.43(\mathrm{~s}, 2 \mathrm{H}), 3.32$ (t, $1 \mathrm{H}, J=4.9 \mathrm{~Hz}), 2.96-2.30(\mathrm{~m}, 20 \mathrm{H}), 1.79-1.41$ (AB-q, 2H, $J=10.6 \mathrm{~Hz}) .{ }^{13} \mathrm{C}$ NMR $\left(50 \mathrm{MHz}, \mathrm{CDCl}_{3}\right) \delta_{\mathrm{c}}: 137.9,129.1$, 128.2, 127.0, 70.8, 62.7, 58.6, 56.9, 52.7, 53.4, 51.5, 46.6, 45.7, 45.4, 43.3, 43.2, 42.1, 41.9, 41.7. IR $\left(v_{\max }\right): 3242.86,2949.29$, $2812.87,1319.78,1284.36 \mathrm{~cm}^{-1}$. HR-ESI $[\mathrm{M}+\mathrm{H}]^{+}$: calcd. 378.2540 , found. 378.2546 .

\subsection{2. $N$-[2-(4-benzylpiperidin-1-yl)ethyl]-5-oxahexacyclo[5.4. $1.0^{2,6} \cdot 0^{3,10} \cdot 0^{4,8} \cdot 0^{9,12}$ Jdodecan-4-amine (18)}

Methanesulfonyl chloride (261 mg, $2.28 \mathrm{mmol})$ dissolved in $10 \mathrm{ml}$ of a 50:40:10 diethyl ether:DCM:triethylamine solvent system was added dropwise to a stirred solution of compound 15 (500 mg, $2.28 \mathrm{mmol}, 1.00$ equiv.) in $20 \mathrm{ml}$ of the same solvent system under nitrogen gas on an external ice bath consisting of ice, acetone and sodium chloride which cooled the reaction mixture to approximately $-8{ }^{\circ} \mathrm{C}$. At the moment of addition, an exothermal reaction took place, gas was expelled and the reaction vessel's temperature increased despite the external ice bath. The reaction was allowed to stir overnight at room temperature. The solvents were evaporated in vacuo and the mixture was dissolved in $10 \mathrm{ml}$ of DCM and washed with 2 $\mathrm{x} 10 \mathrm{ml}$ of brine. The combined organic fractions were dried over $\mathrm{MgSO}_{4}$, filtered and evaporated in vacuo to produce a dark yellow oil. The product $((\mathbf{1 6}, 2-(\{5$-oxahexacyclo $\left[5 \cdot 4 \cdot 1 \cdot 0^{2,6} \cdot 0^{3,10} \cdot 0^{4,8} \cdot 0^{9,12}\right]$ dodecan-4-yl $\}$ amino)ethyl methanesulfonate)) was confirmed to be pure enough for subsequent reactions (Yield $=193 \mathrm{mg}, 20 \%)$. Physical data: ${ }^{1} \mathrm{H}$ NMR (200 $\left.\mathrm{MHz}, \mathrm{CDCl}_{3}\right): \delta_{\mathrm{H}}: 4.68-4.53(\mathrm{t}, 1 \mathrm{H}, J=5.6 \mathrm{~Hz}), 3.57(\mathrm{t}, 2 \mathrm{H}, J$ $=5.8 \mathrm{~Hz}), 3.05(\mathrm{t}, 2 \mathrm{H}, J=5.8 \mathrm{~Hz}), 2.90-2.32(\mathrm{~m}, 9 \mathrm{H}), 1.95-$ 1.46 (AB-q, 2H, $J=10.5)$. Next, 16 (193 mg, $0.65 \mathrm{mmol})$ was reacted with 4-benzylpiperidine $(\mathbf{1 7}, 114 \mathrm{mg}, 0.65 \mathrm{mmol}, 1.00$ equiv.). The reactants were dissolved in $7 \mathrm{ml}$ of acetonitrile and a spatula point $(150-200 \mathrm{mg})$ of potassium carbonate was added. It was then reacted in a microwave reactor for $10 \mathrm{~min}$ at a maximum temperature of $120^{\circ} \mathrm{C}$, a pressure which fluctuated around $90 \mathrm{psi}$ and power output between $50 \mathrm{~W}$ and $100 \mathrm{~W}$. The reaction mixture was then dissolved in $10 \mathrm{ml}$ of DCM and washed with $2 \times 5 \mathrm{ml}$ of water. Further purification by column chromatography was done starting with hexane as mobile phase and gradually incorporating ethyl acetate into the mobile phase at increments of $10 \%$. The product eluded at $50 \%$ ethyl acetate:hexane, but still contained impurities. The eluded crude compound was dissolved in $10 \mathrm{ml}$ of DCM and extracted with $3 \times 10 \mathrm{ml} 0.01 \mathrm{M} \mathrm{HCl}$ solution. The acidic phases were collected and made basic with a $0.1 \mathrm{M} \mathrm{NaOH}$ solution. The compound was then extracted with $3 \times 30 \mathrm{ml}$ of DCM. The organic fractions were collected, dried with $\mathrm{MgSO}_{4}$ overnight, filtered and dried in vacuo to yield the desired compound (18) as a viscous yellow-orange oil (Yield $=23 \mathrm{mg}, 9 \%$ ). Physical data: ${ }^{1} \mathrm{H}$ NMR $\left(200 \mathrm{MHz}, \mathrm{CDCl}_{3}\right): \delta_{\mathrm{H}}: 7.38-7.19(\mathrm{~m}, 5 \mathrm{H})$, $4.62(\mathrm{t}, 1 \mathrm{H}, J=5.6 \mathrm{~Hz}), 3.17-3.13(\mathrm{~d}, 2 \mathrm{H}, J=8.2 \mathrm{~Hz}), 2.79-$ $2.40(\mathrm{~m}, 21 \mathrm{H}), 1.90-1.48$ (AB-q, $2 \mathrm{H}, J=10.5) .{ }^{13} \mathrm{C}$ NMR $(50$ $\left.\mathrm{MHz}, \mathrm{CDCl}_{3}\right): \delta_{\mathrm{c}}: 136.8,128.5,127.4,126.3,82.6,60.9,55.0$, 53.2, 51.9, 47.9, 47.6, 44.7, 44.5, 43.6, 43.4, 41.9, 41.7, 41.6, 
41.3, 29.6. IR $\left(v_{\max }\right): 2961.45,2861.88,1739.92,1341.79$, $1008.16 \mathrm{~cm}^{-1}$. HR-ESI $[\mathrm{M}+\mathrm{H}]^{2+}$ : calcd. 378.2587 , found. 378.2574 .

\subsubsection{5-(3-\{3-[(Piperidin-1-yl)methyl]phenoxy\}propyl)-5-aza- hexacyclo[5.4.1. $\left.0^{2,6} \cdot 0^{3,10} \cdot 0^{4,8} \cdot 0^{9,12}\right]$ dodecan-4-ol (24)}

Pentacyclo $\left[5.4 \cdot 0 \cdot 0^{2,6} \cdot 0^{3.10} \cdot 0^{5,9}\right]$ undecane-8,11-dione $(\mathbf{1 3}, 1.4$ g, $8.04 \mathrm{mmol})$ was reacted with $1.7 \mathrm{~g}(8.04 \mathrm{mmol})$ of $N$-[3-(3piperidin-1-ylmethylphenoxy)propyl]amine (22) in $10 \mathrm{ml}$ dry THF at $-10{ }^{\circ} \mathrm{C}$. The carbinolamine that formed after $10 \mathrm{~min}$ was filtered off and refluxed under Dean-Stark conditions for 1 hour in benzene. The benzene was evaporated under vacuum and the residue was dissolved in $6 \mathrm{ml}$ dry methanol and $30 \mathrm{ml}$ dry THF. To this, $0.3 \mathrm{~g} \mathrm{NaBH}_{3} \mathrm{CN}$ was added as a reducing agent. The mixture was stirred overnight at room temperature. The methanol and THF were evaporated in vacuo and the residue was extracted with $4 \times 25 \mathrm{ml}$ DCM and the organic fraction was dried with $\mathrm{MgSO}_{4}$, filtered and evaporated in vacuo. The desired product (24) was obtained as a yellow oily substance after column chromatography using DCM: EtO Ac:PE, 1:1:1 $(\mathrm{Rf}=0.42)$, as mobile phase (Yield: $0.43 \mathrm{~g}, 1.09$ mmol, 13\%). Physical data: ${ }^{1} \mathrm{H}$ NMR (300 MHz, $\left.\mathrm{CDCl}_{3}\right) \delta_{\mathrm{H}}$ : $7.26(\mathrm{t}, 1 \mathrm{H}, J=5.8 \mathrm{~Hz}), 6.95-6.88(\mathrm{~m}, 1 \mathrm{H}), 6.80-6.74(\mathrm{~m}, 2 \mathrm{H})$, $4.10(\mathrm{t}, 2 \mathrm{H}, J=5.1 \mathrm{~Hz}), 3.63(\mathrm{t}, 1 \mathrm{H}, J=5.0 \mathrm{~Hz}), 3.52(\mathrm{~s}, 2 \mathrm{H})$ $3.13(\mathrm{t}, 2 \mathrm{H}, J=5.2 \mathrm{~Hz}), 3.09-2.55(\mathrm{~m}, 14 \mathrm{H}), 2.10-1.94(\mathrm{~m}$, $4 \mathrm{H}), 1.85-1.55$ (AB-q, $2 \mathrm{H}, J=11.3 \mathrm{~Hz}), 1.53-1.45(\mathrm{~m}, 2 \mathrm{H}) .{ }^{13} \mathrm{C}$ NMR $\left(75 \mathrm{MHz}, \mathrm{CDCl}_{3}\right) \delta_{\mathrm{c}}: 158.0,140.2,129.1,122.0,115.2$, 113.0, 66.9, 64.8, 63.6, 54.8, 54.3, 54.3, 53.6, 46.3, 44.6, 43.9, $43.8,43.1,41.9,41.6,41.240 .9,38.9,26.9,26.0,24.2$ IR $\left(v_{\max }\right): 3342.8,2969.1,2865.4,1731.0,1337.7,1274.1,1098.0$, $1557.9 \mathrm{~cm}^{-1}$. HR-ESI [M+H]: calcd. 407.2693, found. 407. 2697.

\subsection{4. $\mathrm{N}$-(3-\{3-[(Piperidin-1-yl)methyl]phenoxy\}propyl)-5-ox- ahexacyclo[5.4.1.0 $\left.0^{2,6} \cdot 0^{3,10} \cdot 0^{4,8} \cdot 0^{9,12}\right]$ dodecan-4-amine (25)}

Pentacyclo[5.4.0. $\left.0^{2,6} .0^{3.10} .0^{5,9}\right]$ undecane-8,11-dione (13, 1.4 g, $8.04 \mathrm{mmol})$ was reacted with $1.7 \mathrm{~g}(8.04 \mathrm{mmol})$ of $\mathrm{N}$-[3-(3piperidin-1-ylmethylphenoxy)propyl]amine (22) in $10 \mathrm{ml}$ dry THF at $-10{ }^{\circ} \mathrm{C}$. The carbinolamine that formed after $10 \mathrm{~min}$ was filtered off and refluxed under Dean-Stark conditions for 1 hour in benzene. The benzene was evaporated under vacuum and the residue was dissolved in $6 \mathrm{ml}$ dry methanol and $30 \mathrm{ml}$ dry THF. To this $0.30 \mathrm{~g} \mathrm{NaBH}_{4}$ was added as reducing agent. The mixture was stirred overnight at room temperature. The methanol and THF were evaporated under vacuum and the residue was extracted with $4 \times 25 \mathrm{ml} \mathrm{DCM}$ and the organic fraction was dried with magnesium sulphate, filtered and evaporated. The desired product (25) was obtained as an light yellow oily substance after column chromatography using DCM:EtOAc:PE, 1:1:1 ( $\mathrm{Rf}=0.43)$, as mobile phase. (Yield: $1.31 \mathrm{~g}, 35 \%)$. Physical data: ${ }^{1} \mathrm{H}$ NMR $(300 \mathrm{MHz}, \mathrm{CDCI}) \delta_{\mathrm{H}}$ : $7.20(\mathrm{t}, 1 \mathrm{H}, \mathrm{J}=8.2 \mathrm{~Hz}), 6.93-6.85(\mathrm{~m}, 2 \mathrm{H}), 6.78-6.74(\mathrm{~m}, 1 \mathrm{H})$, $4.7(\mathrm{t}, 1 \mathrm{H}, J=5.4 \mathrm{~Hz}), 4.02(\mathrm{t}, 2 \mathrm{H}, J=5.2 \mathrm{~Hz}), 3.43(\mathrm{~s}, 2 \mathrm{H})$, $3.17(\mathrm{t}, 2 \mathrm{H}, J=5.3 \mathrm{~Hz}), 3.10-3.01(\mathrm{~m}, 4 \mathrm{H}), 2.96-2.65(\mathrm{~m}$, $10 \mathrm{H}), 2.15-2.09(\mathrm{~m}, 4 \mathrm{H}), 2.05-1.87$ (AB-q, $2 \mathrm{H}, J=11.5)$, $1.60-1.53(\mathrm{~m}, 2 \mathrm{H}) ;{ }^{13} \mathrm{C}$ NMR $(75 \mathrm{MHz}, \mathrm{CDCI}) \delta_{\mathrm{c}}: 159,140.0$, 128.1, 122.0, 115.4, 112.6, 110.0, 82.3, 65.2, 64.9, 64.0, 54.9, $54.8,54.6,54.0,46.0,44.5,43.9,43.5,43.0,41.5,41.240 .5$
$38.8,26.8,26.2,24.2$. IR $\left(v_{\max }\right): 3357.2,2964.7,2863.9$, 1706.0, 1211.2, $1131.8 \mathrm{~cm}^{-1}$; HR-ESI [M+H]: calcd. 407.2693, found. 407.2696.

\subsubsection{5- [2- (Piperidin-1-yl) ethyl]-5- azahexacyclo [5.4.1.0 ${ }^{2,6}$. $\left.0^{3,10} \cdot 0^{4,8} \cdot 0^{9,12}\right]$ dodecan-4-ol (27)}

Pentacyclo $\left[5 \cdot 4 \cdot 0.0^{2,6} \cdot 0^{3.10} \cdot 0^{5,9}\right]$ undecane-8,11-dione $(\mathbf{1 3}, 1 \mathrm{~g}$, $8.04 \mathrm{mmol})$ was reacted with $1 \mathrm{ml}$ of 1 -(2-aminoethyl) piperidine $(\mathbf{2 6}, 5.74 \mathrm{mmol})$ in $10 \mathrm{ml}$ dry $\mathrm{THF}$ at $-10{ }^{\circ} \mathrm{C}$. The carbinolamine that formed was filtered off and refluxed under Dean-Stark conditions for 1 hour in benzene. The benzene was evaporated in vacuo and the residue was dissolved in $6 \mathrm{ml}$ dry methanol, $30 \mathrm{ml}$ dry THF and $0.3 \mathrm{~g} \mathrm{NaBH}_{3} \mathrm{CN}$ was added as reducing agent and the mixture was stirred overnight at room temperature. The methanol and THF were evaporated in vacuo and the residue was extracted with $4 \times 25 \mathrm{ml}$ DCM, dried with $\mathrm{MgSO}_{4}$, filtered and evaporated. The desired product (27) was obtained as a yellow oily substance after column chromatography using DCM:EtOAc:PE, 1:1:1 $(\mathrm{Rf}=0.31)$, as mobile phase. (Yield: $0.70 \mathrm{~g}, 2.33 \mathrm{mmol}, 41 \%$ ). Physical data: ${ }^{1} \mathrm{H}$ NMR $\left(300 \mathrm{MHz}, \mathrm{CDCl}_{3}\right) \delta_{\mathrm{H}}: 3.80(\mathrm{t}, 1 \mathrm{H}, J=5.3 \mathrm{~Hz})$, 2.80-2.10 (m, 16H), $1.90(\mathrm{~d}, 1 \mathrm{H}, J=10.40 \mathrm{~Hz}), 1.75-1.40(\mathrm{~m}$, $7 \mathrm{H}) ;{ }^{13} \mathrm{C}$ NMR $\left(75 \mathrm{MHz}, \mathrm{CDCI}_{3}\right) \delta_{\mathrm{c}}: 82.4,71.9,59.1,58.1$, $54.9,54.8,45.0,44.8,43.0,42.6,40.0,35.2,34.4,30.5,26.0$, 24.6; IR ( $\left.v_{\max }\right): 3000,2938.1,2860.3,2324.8,2168.4 \mathrm{~cm}^{-1}$; HRESI [M+H]: calcd. 287.2118, found. 287.2121.

\subsection{Sigma-1 Receptor Binding Affinity Studies}

Binding affinities for the $\sigma^{1} \mathrm{R}$ were determined as described previously [41, 42]. Briefly, rat liver lysates were incubated with $3 \mathrm{nM}\left[{ }^{3} \mathrm{H}\right](+)$-pentazocine (Perkin Elmer USA), 100 $\mathrm{ug} / \mathrm{mL}$ tissue lysate and compounds in $50 \mathrm{mM}$ Tris $\mathrm{pH}$ 8.0. After 1 hour incubation, the reaction was terminated with the addition of $1 \mathrm{ml}$ cold $50 \mathrm{mM}$ Tris $\mathrm{pH} 8.0$ buffer and filtered through Wathman B filter paper using a vacuum manifold. The filters were pre-soaked in $0.3 \%$ polyethylene imine for at least $30 \mathrm{~min}$ before the experiment was terminated. The filters were additionally washed twice with $1 \mathrm{ml}$ cold buffer. The remaining radioactivity remaining on the filter paper was counted using scintillation counting. All data analysis, calculation and graphs were done using Prism 6.0 ${ }^{\circledR}$ (GraphPhad, La Jolla, CA). Experiments were repeated three times on different tissue preparations with three determinations in each replicate. The final results were expressed as $\mathrm{K} i$ and $\mathrm{IC}_{50}$ values.

\subsection{Sigma-1 Receptor Docking Studies}

The docking studies were performed using the recently published $\sigma_{1} \mathrm{R}$ crystal structure (PDB: 5HK2) [43]. The Molecular Operating Environment (MOE) 2015 software suite was used for the docking studies with the following protocol. (1) The receptor protein structure was checked for missing atoms, bonds and contacts. (2) Hydrogens and partial charges were added using the protonate $3 \mathrm{D}$ application in MOE. Protein structure preparation was done by setting the $\mathrm{pH}$ of the protein at 7.4. (3) The ligands were constructed using the builder module and were energy minimized using CHARMm. (4) Ligands were docked within the $\sigma_{1} R$ active sites using MOEDock application. The active site was selected based on 
the position of the co-crystallised ligand, 4-IBP. The docking algorithm which was chosen for these experiments was based on induced fit docking to allow for flexible interactions of the test compounds with the receptor. (5) The top binding best pose of each compound was visually inspected and the interactions with binding pocket residues were analyzed. To determine the accuracy of this docking protocol, the cocrystallised ligand, 4-IBP (PDB ID: 5HK2), was redocked into the $\sigma_{1} R$ active site. The best ranked solution of 4-IBP exhibited an RMSD values of less than $0.56 \AA$ from the position of the co-crystallised ligand. In general, RMSD values smaller than $2.0 \AA$, indicate that the docking protocol is capable of accurately predicting the binding orientation of the co-crystallised ligand $[49,50]$. This protocol was thus deemed to be suitable for the docking of the test compounds.

\subsection{Voltage Gated Calcium Channel Assay}

The fluorescent ratiometric indicator, Mag-Fura-2/AM, and a Bio-Tek ${ }^{\circledR}$ fluorescent plate reader were used to evaluate the influence of the test compounds on calcium homeostasis via the VGCC utilizing murine synaptoneurosomes at $37^{\circ} \mathrm{C}$. The preparation of synaptoneurosomes, solutions and experimental techniques was similar to those of published studies $[44,45]$. All data analysis, calculation and graphs were conducted using Prism 6.0 ${ }^{\circledR}$ (GraphPhad, La Jolla, CA). Data analysis was carried out using the Student Newman Keuls multiple range test and the level of significance was accepted at $p<0.05$. Experiments were repeated three times on different tissue preparations with three determinations in each replicate

A $1990 \mu 1$ suspension of synaptoneurosomes was allowed to reach room temperature, thereafter $10 \mu \mathrm{l}$ of Fura-2 AM (1 $\mathrm{mM}$ in DMSO) was added to produce a final concentration of 5 $\mu \mathrm{M}$. Synaptoneurosomes were then incubated at $37^{\circ} \mathrm{C}$ for 30 min after which the suspension was centrifuged on a desktop centrifuge at $7000 \mathrm{~g}$ for $5 \mathrm{~min}$ and the supernatant decanted to remove all extracellular Fura-2 AM. The resulting pellet was resuspended in $2 \mathrm{mM} \mathrm{CaCl}_{2}$ containing buffer to obtain a final protein concentration of $0.6 \mathrm{mg} / \mathrm{ml}$.

For the screening test, $10 \mathrm{mM}$ stock solutions of the compounds in DMSO were prepared, with the control containing $1 \%$ DMSO and no test compound. The individual stock solutions were added in $2 \mu 1$ portions to a 96 well plate in triplicate followed by the addition of $200 \mu \mathrm{l}$ of synaptoneurosomal-Fura-2 AM solution prepared above. This gave rise to a final concentration of $100 \mu \mathrm{M}$ of the compounds. The 96 well plate was shaken and incubated for $30 \mathrm{~min}$ at $37{ }^{\circ} \mathrm{C}$ and used immediately after incubation. The measurement was then performed at $37{ }^{\circ} \mathrm{C}$ in a 96 well plate using dual wavelength excitation at $340 \mathrm{~nm}$ and $380 \mathrm{~nm}$. The resting fluorescence was measured at $510 \mathrm{~nm}$ after which the changes in fluorescence intensity following the addition of $10 \mu \mathrm{KCl}(140 \mathrm{mM})$ depolarization solution using auto-injectors were recorded over a period of $5 \mathrm{~min}$. The changes in fluorescence indicated the effect of the test compound on calcium flux. The data obtained from the fluorescent readings of each well were expressed in the form of a ratio (340 $\mathrm{nm}$ reading / $380 \mathrm{~nm}$ reading). This ratio indicated the net movement of $\mathrm{Ca}^{2+}$ ions across the membrane as it represents the ratio between unbound- $\mathrm{Ca}^{2+}$ and $\mathrm{Ca}^{2+}$-bound to Fura-2 AM. The average ratio over a 10 second interval before stimulation was subtracted from the average ratio 10 second after stimulation to give the net change in $\mathrm{Ca}^{2+}$ movement $(\mathrm{Nc})$ across the membrane. This calculation was performed for each individual well and the averages of wells containing the same test compound were calculated $\left(\mathrm{Nc}_{\mathrm{Ave}}\right)$. These averages of three independent experiments were used to calculate the percentage inhibition of the test compounds relative to the control by the use of the following equation:

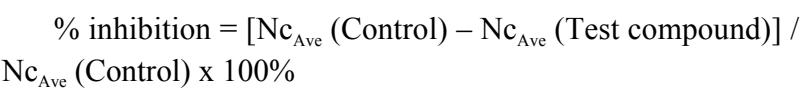

\section{RESULTS \& DISCUSSION}

\subsection{Chemistry}

To obtain the required novel oxa- and aza-hexacyclododecylamine compounds (12, 18, 24, 25 and 27), bimolecular nucleophilic substitution, nucleophilic addition and selective reduction methods were utilized. The synthesis of the aza-HCD compound $\mathbf{1 2}$ commenced from a series of microwave-assisted $\mathrm{S}_{\mathrm{N}} 2$ reactions to produce the intermediate 2-(4-benzylpiperazin-1-yl)ethanamine (8, Scheme $\mathbf{1})$, as previously des-cribed [38]. Compound $\mathbf{8}$ was conjugated to the penta-cycloundecane (PCU) ketal (9) [39] through microwave irradiation at $100{ }^{\circ} \mathrm{C}$, $150 \mathrm{~W}$ and 150 psi for 30 minutes to produce the PCU-imine (10). The PCU-imine was reduced using $\mathrm{NaBH}_{4}$ to produce the endo-amine (11) and the final aza-HCD (12) was obtained through hydrolysis and subsequent transannular cyclization using $3 \mathrm{M} \mathrm{HCl} /$ acetone.

To synthesize the oxa-HCD derivative (18), the obtained 2aminoethanol-HCD structure (15, Scheme 2) [28] was reacted with methanesulfonyl chloride to provide a leaving group for reaction with the $N$-benzylpiperazine. Mesylate compounds generally show selectivity for amine groups over hydroxyl groups, but the NMR of compound $\mathbf{1 6}$ and the NMR, IR and MS data of $\mathbf{1 8}$ confirmed that the mesylate substitution of $\mathbf{1 6}$ took place on the hydroxyl moiety. This is probably due to steric hindrance from the hexacyclododecane structure at the amine. The benzyl piperidine (17) was then capable of displacing the methane-sulfonyl group and the final compound (18) was obtained using microwave-irradiation conditions (Scheme 2).

Compounds $\mathbf{2 1}$ and $\mathbf{2 2}$ were synthesised according to the methods proposed by Buschauer et al., (1985) [40]. Intermediate $\mathbf{2 2}$ served as the functional moiety that was conjugated to $\mathbf{1 3}$ in order to obtain imine-PCU compound 23. Further reduction using $\mathrm{NaCNBH}_{3}$ and $\mathrm{NaBH}_{4}$ produced the desired aza-HCD (24) and oxa-HCD (25) respectively (Scheme 3). Compound 27 was synthesised by conjugating 13 and 26 followed by Dean-Stark dehydration and subsequent reductive amination using $\mathrm{NaCNBH}_{3}$ (Scheme 4). 


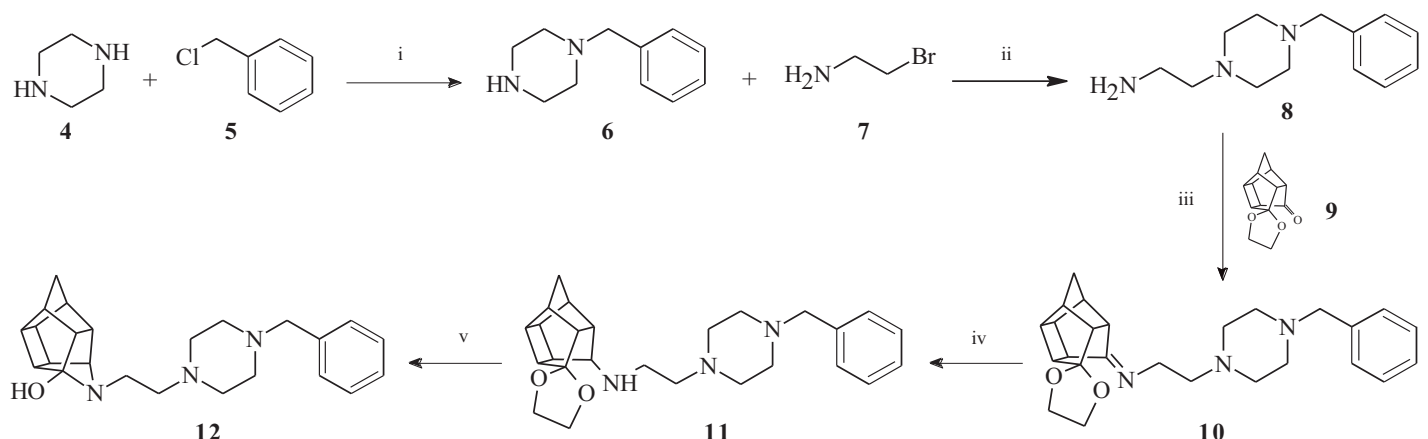

Scheme 1. Reagents and conditions: (i) $\mathrm{CH}_{3} \mathrm{CN}, \mathrm{MW}, 100{ }^{\circ} \mathrm{C}, 150 \mathrm{~W}, 100 \mathrm{psi}, 5 \mathrm{~min}, 94 \%$; (ii) $\mathrm{CH}_{3} \mathrm{CN}, \mathrm{MW}, 100{ }^{\circ} \mathrm{C}, 150 \mathrm{~W}, 100 \mathrm{psi}, 10 \mathrm{~min}, 92 \%$ yield from 5; (iii) $\mathrm{EtOH}, \mathrm{MW}, 100{ }^{\circ} \mathrm{C}, 150 \mathrm{~W}, 150 \mathrm{psi}, 30 \mathrm{~min}$, quantitative yield; (iv) $\mathrm{EtOH} \mathrm{NaBH}_{4}, \mathrm{rt}, 8 \mathrm{~h}$; (v) acetone, $3 \mathrm{M} \mathrm{HCl}(\mathrm{aq}), 6 \mathrm{~h}, 53 \%$ [38].

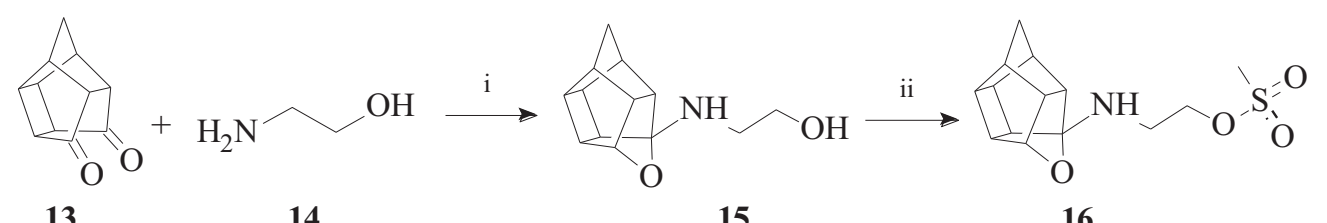

13

14

15

16

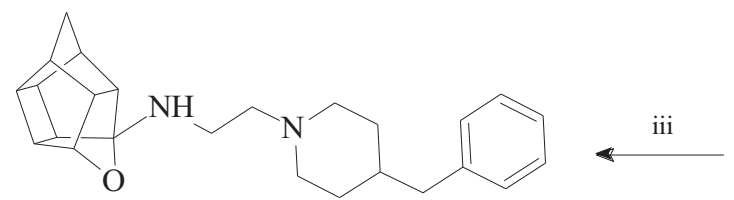

18<smiles>c1ccc(CC2CCNCC2)cc1</smiles>

17

Scheme 2. Reagents and conditions: (i) THF, $\mathrm{MeOH}, \mathrm{NaBH}_{4}, \mathrm{rt}, 4 \mathrm{~h}, 32 \%$; (ii) Mesyl chloride, $\mathrm{DCM}, \mathrm{Et}_{3} \mathrm{~N}, \mathrm{Et}_{2} \mathrm{O},-8{ }^{\circ} \mathrm{C}$, overnight, $20 \%$; (iii) $\mathrm{CH}_{3} \mathrm{CN}$, $\mathrm{K}_{2} \mathrm{CO}_{3}$, EtOH, $\mathrm{MW}, 120^{\circ} \mathrm{C}, 100 \mathrm{~W}, 90 \mathrm{psi}, 10 \mathrm{~min}, 9.3 \%$.<smiles>C1CCNCC1</smiles>

19<smiles>O=Cc1cccc(O)c1</smiles>

20<smiles>Oc1cccc(CN2CCCCC2)c1</smiles>

21<smiles>NCCCOc1cccc(CN2CCCCC2)c1</smiles>

vi<smiles>O=C1C2CC3C(=O)C1N(CCCOc1cccc(CN4CCCCC4)c1)C3C2</smiles>

25

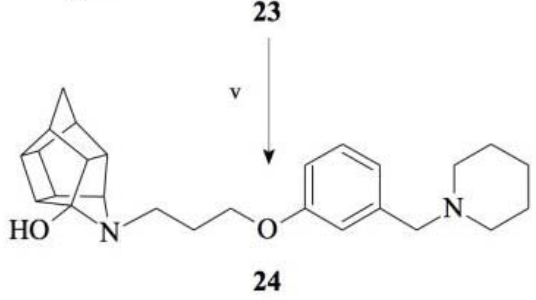

Scheme 3. Reagents and conditions: (i) Formic acid, $110^{\circ} \mathrm{C}$ for $2 \mathrm{~h}, 74 \%$; (ii) DMF, 3-chloropropylamine, $\mathrm{NaOH}, 80-90{ }^{\circ} \mathrm{C}, 2 \mathrm{~h}, 69 \%$; (iii) $\mathrm{THF}$, -10 ${ }^{\circ} \mathrm{C}, 10 \mathrm{~min}$; (iv) benzene, Dean-Stark, 1 h; (v) $\mathrm{MeOH} / \mathrm{AcOH}, \mathrm{NaCNBH}_{3}$, rt, 2 h, 13\%; (vi) THF/MeOH, $\mathrm{NaBH}_{4}$, rt, 8 h 35\%; 


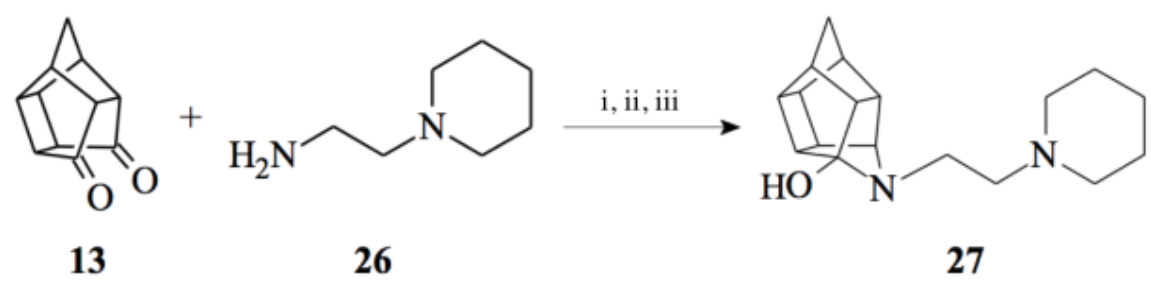

Scheme 4. (i) $\mathrm{THF},-10{ }^{\circ} \mathrm{C}, 10 \mathrm{~min}$; (ii) benzene, Dean-Stark, $1 \mathrm{~h}$ (iii) $\mathrm{MeOH} / \mathrm{AcOH}, \mathrm{NaCNBH}_{3}, \mathrm{rt}, 2 \mathrm{~h}, 17 \%$.

\subsubsection{Sigma-1 Receptor Binding Affinity}

$\sigma_{1} \mathrm{R}$ binding affinity of the test compounds (Table $\mathbf{1}$ ) was evaluated according to the method by Matsumoto et al. In the experiments, rat liver membranes were used as the source of $\sigma_{1}$ Rs. $\left[{ }^{3} \mathrm{H}\right](+)$-pentazocine was used as a radioligand and all stock solutions and procedures including data processing were adhered to as previously described [41]. The final results were expressed as $\mathrm{K} i$ and $\mathrm{IC}_{50}$ values and further compared to known $\sigma_{1} \mathrm{R}$ ligands. The novel HCD compounds $(\mathbf{1 2}, \mathbf{1 8}, \mathbf{2 4}, \mathbf{2 5}$ and 27) showed $\sigma_{1} R$ affinities in the same range as that described for similar HCD structures (NGP1-01 and 1-3, Table 1) with 5[2-(4-benzylpiperazin-1-yl)ethyl]-5- azahexacyclo [5.4.1.0 $0^{2,6}$ $\left..0^{3,10} \cdot 0^{4,8} \cdot 0^{9,12}\right]$ dodecan-4-ol (12) showing the best affinity (67 $\mathrm{nM})$. Amongst the tested compounds, the aza structures generally are more favourable for $\sigma_{1} \mathrm{R}$ binding than their oxa counterparts (cf. 12 and 18; 24 and 25). With the inclusion of the amine heterocycle between the cage and the aromatic ring (12 and 18) $\sigma_{1} \mathrm{R}$ affinity was retained (cf. 12 with 2 and 3 ) or even improved (cf. 18 with NGP1-01 and 1) (Table 1). The addition of the HCD scaffold showed a definite increase in $\sigma_{1} \mathrm{R}$ binding affinity from the respective intermediate counterparts without the HCD scaffold (cf. 8, 12 and 18; 22 and 24). Compounds $\mathbf{2 4}$ and $\mathbf{2 5}$ that consisted of the HCD connected to a phenyl ether with a terminal piperidine moiety, when compared to compounds $\mathbf{1 2}$ and $\mathbf{1 8}$, showed a reduced affinity and suggested that the HCD linked through an aminecontaining heterocycle connected to a benzyl moiety is preferable for $\sigma_{1} \mathrm{R}$ affinity and supports the pharmacophore model suggested by Glennon et al. [42] The aza compound 24 $(\mathrm{K} i=0.215 \mu \mathrm{M})$ compared to the oxa compound $25(\mathrm{~K} i=$ $11.855 \mu \mathrm{M}$ ) showed a significant increase in $\sigma_{1} \mathrm{R}$ binding affinity which strongly suggests that the aza compound is preferable for the $\sigma_{1} R$ affinity. This preference for the azastructure is further evident in the binding affinities observed for the aza-HCDs 2, 3, 12, 24 and 27. This is also in agreement with the previously published $\sigma_{1} \mathrm{R}$ affinities for HCD derivatives $[33,39]$. Intermediate compound 21 has good affinity $(\mathrm{K} i=0.349 \mu \mathrm{M})$ as it possesses the necessary features of the pharmacophore model including the basic amine and the adjacent lipophilic region which support this result. It is also important to note that intermediate compound $22(\mathrm{~K} i=0.251$ $\mu \mathrm{M})$, despite the lack of a second lipophilic binding area, still showed significant $\sigma_{1} \mathrm{R}$ binding. Finally, the comparison of compound $12(0.067 \mu \mathrm{M})$ with compound $27(\mathrm{~K} i=0.469 \mu \mathrm{M})$ indicates that the addition of $N$-benzyl group is favoured for $\sigma_{1} R$ affinity. When the activities of $\mathbf{1 2}$ and $\mathbf{2 7}$ are compared to $\mathbf{2}$ and $\mathbf{3}$, it is clear that the inclusion of the amine heterocycle leads to $\sigma_{1} \mathrm{R}$ binding affinity in the same range. This suggests that the additional amine heterocycles retained the optimal alignment of compound $\mathbf{1 2}$ and $\mathbf{2 7}$ for $\sigma_{1} \mathrm{R}$ binding affinity as suggested by the pharmacophore model proposed by Glennon et al. [42].

\subsubsection{Sigma-1 Receptor Docking Studies}

To gain insight into the mode of interaction between the compounds, $\sigma_{1} \mathrm{R}$, docking studies were performed using the Molecular Operating Environment (MOE) 2016 software package and the recently published crystal structure of the $\sigma_{1} R$ (PDB:5HK2) [43]. The docking results indicate that the HCU amine moiety seemed to play an important role in orienting the compounds for favorable hydrogen bonding interactions with several amino acids, specifically HIS154 and GLU172. For instance, compound 2, 3, 12 and 24 were found to form lipophilic interactions between the HCD carbons and HIS154, and the HC hydroxyl moiety with GLU172 (Fig. 2) through a hydrogen bond. Compound 18, an oxa-HCD showed an interaction with HIS154 but lacked the interaction with GLU172 as observed for the aza-HCDs $\mathbf{2 , 3}$ and 12. This may explain why better $\sigma_{1} \mathrm{R}$ affinity was observed for the azaHCDs. Compound 8 without the HCD moiety did not show interactions with these two amino acids, which may account for the loss of affinity as compared to compounds $\mathbf{1 2}$ and $\mathbf{1 8}$ for instance. Compound 27, that lacks the benzyl group observed in $\mathbf{1 2}$ and 18, adopted an orientation where a hydrogen bond is observed between the hydroxyl moieties of the aza-HCD and TYR120. The $\mathrm{K}_{i}$ value of $\mathbf{2 7}$ was significantly higher compared to $\mathbf{1 2}$ and 18. This indicates that the benzyl moiety of $\mathbf{1 2}$ and $\mathbf{1 8}$ is important to enable optimal alignment of both the amine heterocycle and aza-HCD of these molecules within the $\sigma_{1} \mathrm{R}$ binding pocket, enabling important interactions with HIS154 and GLU172.

\subsection{Voltage-gated Calcium Channel Activity}

All HCD amine compounds (Table 1) were screened at 100 $\mu \mathrm{M}$ for their potential inhibitory activity on the VGCC as previously described [44] using the fluorescent ratiometric indicator Fura-2 AM. Fresh synaptoneurosomes were prepared from rat brain homogenate [45] and incubated with Fura-2 AM. Thereafter the test compounds were incubated for 30 minutes and $140 \mathrm{mM} \mathrm{KCl}$ solution was added to depolarize the cell membranes to stimulate calcium influx. Calcium influx was then monitored based on the fluorescence intensity relative to 
Table 1. Summary of effects of the hexacyclododecylamine derivatives and related compounds on affinity for sigma-1 receptors and voltage gated calcium channel modulation.

\begin{tabular}{|c|c|c|c|c|}
\hline \multirow[t]{2}{*}{ Number } & \multirow[t]{2}{*}{ Structure } & \multicolumn{2}{|c|}{$\sigma_{1} R$ Affinity } & \multirow{2}{*}{$\begin{array}{c}\% \mathrm{Ca}^{2+} \text { Flux Inhibition } \\
\mathrm{KCl}[100 \mu \mathrm{M}]\end{array}$} \\
\hline & & $\mathrm{Ki}(\mu \mathrm{M})$ & $\mathrm{IC}_{50}(\mu \mathrm{M})$ & \\
\hline \multirow[t]{2}{*}{ Amantadine } & & & & \\
\hline & & $7.44[46]$ & 15.24 & $3 \%$ \\
\hline \multirow[t]{2}{*}{ NGP1-01 } & & & & \\
\hline & & 0.869 [33] & 1.78 & $\begin{array}{c}52 \% * * \\
\mathrm{IC}_{50}=86 \mathrm{uM}\end{array}$ \\
\hline \multirow[t]{2}{*}{1} & & & & \\
\hline & & $0.752[33]$ & 1.54 & $\begin{array}{c}89 \% * * * \\
\mathrm{IC}_{50}=51 \mathrm{uM}\end{array}$ \\
\hline \multirow[t]{2}{*}{2} & & & & \\
\hline & & 0.103 [33] & 0.211 & $\begin{array}{c}>95 \% * * * \\
\mathrm{IC}_{50}=35 \mathrm{uM}\end{array}$ \\
\hline \multirow[t]{2}{*}{3} & & & & \\
\hline & & $0.020[33]$ & 0.041 & $\begin{array}{c}>95 \% * * \\
\mathrm{IC}_{50}=8 \mathrm{uM}\end{array}$ \\
\hline \multirow[t]{2}{*}{8} & & & & \\
\hline & & 1.132 & 2.34 & nd \\
\hline \multirow[t]{2}{*}{12} & & & & \\
\hline & & 0.067 & 0.139 & $\mathrm{IC}_{50}=<100 \mu \mathrm{M}$ \\
\hline \multirow[t]{2}{*}{18} & & & & \\
\hline & & 0.132 & 0.273 & $26 \%$ \\
\hline \multirow[t]{2}{*}{21} & & & & \\
\hline & & 0.349 & 0.723 & nd \\
\hline \multirow[t]{2}{*}{22} & & & & \\
\hline & & 0.251 & 0.518 & nd \\
\hline \multirow[t]{2}{*}{24} & & & & \\
\hline & & 0.215 & 0.445 & $\mathrm{IC}_{50}=9.28 \mu \mathrm{M}$ \\
\hline \multirow[t]{2}{*}{25} & & & & \\
\hline & & 11.855 & 24.5 & $25 \%$ \\
\hline \multirow[t]{2}{*}{27} & & & & \\
\hline & & 0.469 & 0.971 & $\begin{array}{c}79 \% * * * \\
\mathrm{IC}_{50}=9.80 \mu \mathrm{M}\end{array}$ \\
\hline Nimodipine & - & nd & nd & $\begin{array}{c}>95 \% * * * \\
\mathrm{IC}_{50}=0.008 \mu \mathrm{M}\end{array}$ \\
\hline
\end{tabular}

${ }^{a}$ Data taken from reference [46]. ${ }^{b}$ Data taken from reference [33]. Statistical analysis was performed on raw data, with asterisks indicating significant inhibitory effect [(*) $\mathrm{p}$ $\left.<0.05,(* *) \mathrm{p}<0.01,\left({ }^{* * *}\right) \mathrm{p}<0.001\right]$ relative to the control. n.d. $=$ not determined. 

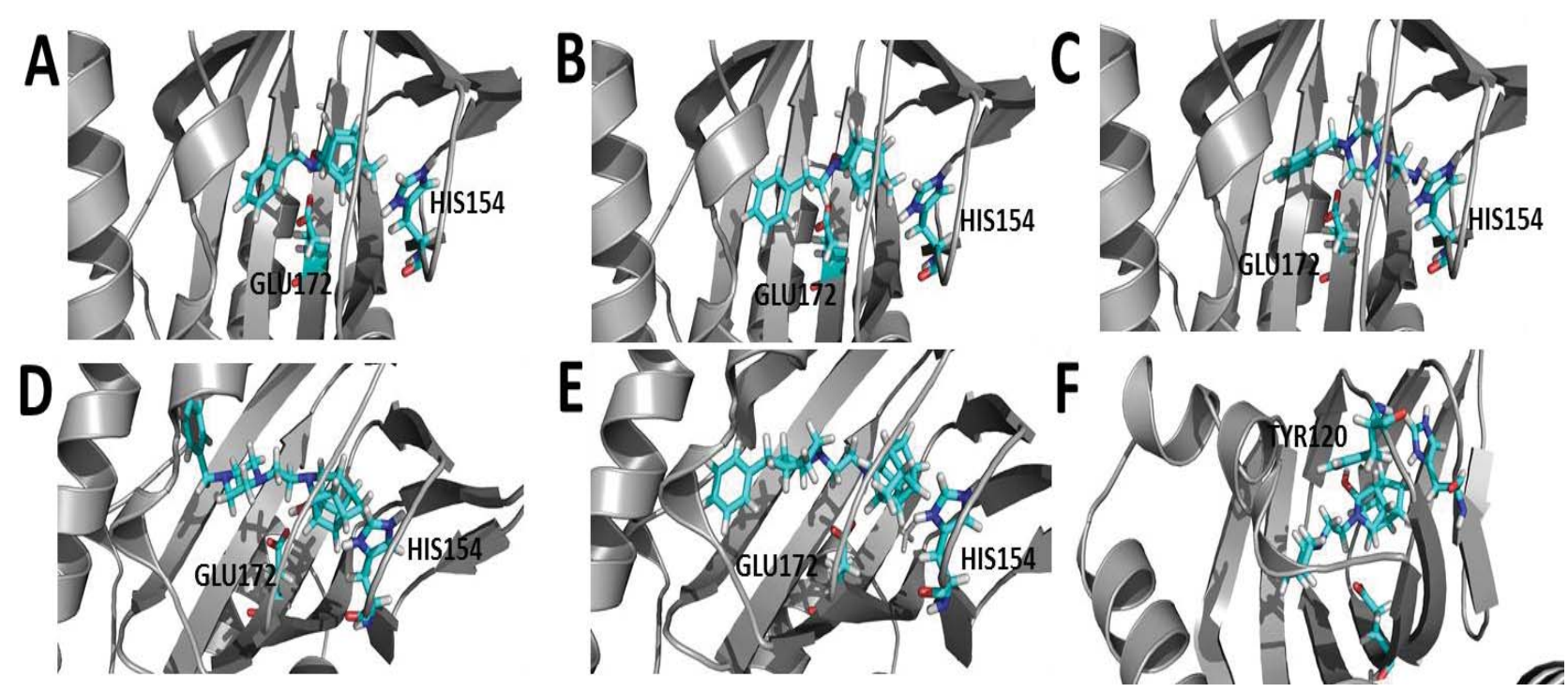

Fig. (2). Docking studies of compounds in $\sigma_{1}$ R. Compounds A) 2, B) 3, C) 8, D) 12, E) 18 and F) 27. The three amino acids that were found to play a role in binding of the HCD amines were HIS154, GLU172 and TYR120. The aza-HCD moiety provides for the optimal orientation to allow for hydrogen bonding with HIS154 and GLU172.

that of a blank control (without inhibiting compound) over a 5 minute period. Two positive controls were included in the VGCC assay; nimodipine, a commercially available dihydropyridine calcium channel blocker and NGP1-01, the prototype HCD compound. Amantadine, a polycyclic NMDA receptor channel inhibitor, was also included as a negative control. Dose-response curves were plotted for selected compounds which showed a high degree of VGCC inhibition at $100 \mu \mathrm{M}$. The novel aza derivatives $\mathbf{2 4}$ and $\mathbf{2 7}$ exhibited comparable activities $\left(\mathrm{IC}_{50}<10 \mu \mathrm{M}\right)$ in the $\mathrm{KCl}$ initiated calcium flux assays to NGP1-01 $\left(\mathrm{IC}_{50}=86 \mu \mathrm{M}\right)$ and related HCD's 1-3 $\left(\mathrm{IC}_{50}\right.$ $=8-51 \mu \mathrm{M})$. The aza-HCD compound (12) showed moderate calcium flux inhibition $\left(\mathrm{IC}_{50}<100 \mu \mathrm{M}\right)$ and the two oxa-HCD derivatives $\mathbf{1 8}$ and $\mathbf{2 5}$ exhibited the weakest calcium flux inhibition $(26 \%$ and $25 \%$ ) at $100 \mu \mathrm{M}$ (Table 1). From the VGCC results compounds 12, 24 and $\mathbf{2 7}$ can be considered as lead compounds to develop more potent calcium channel inhibitors.

\section{CONCLUSION}

The synthesised HCD derivatives had inhibitory effects on calcium flux and thus decreased intracellular calcium concentration. In many cases, this effect might be linked to the compounds' interaction with sigma receptors present in the synaptoneurosomal preparation and implicates $\sigma_{1} \mathrm{R}$ antagonism. This is corroborated by the correlation observed between the VGCC inhibitory activity and the $\sigma_{1}$ R affinity of NGP1-01, $\mathbf{1}$, $\mathbf{2 , 3}$ and between $\mathbf{1 2}$ and $\mathbf{1 8}$, and $\mathbf{2 4}$ and $\mathbf{2 5}-$ as the $\sigma_{1} \mathrm{R}$ affinity for these compounds increased, the VGCC inhibition activity also increased. The decrease in intracellular calcium detected in the VGCC assays could thus in part be linked to the interaction of these compounds with $\sigma_{1} R$ in this assay. The compounds where this correlation is not observed will also be useful in identifying structural features to manipulate the specific or dual activities of future structures in this series. The observations and conclusions obtained from this study do not exclude interaction with other receptors such as the NMDA and AMPA/KA receptors and further investigation to characterise the calcium modulating effects of these compounds will follow.

Test compounds 12, 24 and $\mathbf{2 7}$ show potential to act as dual $\sigma_{1} \mathrm{R}$ antagonists and VGCC blockers. Compound $\mathbf{1 2}$ exhibited VGCC inhibition in the same range as NGP1-01 with 24 and 27 showing activity comparable to the most potent azaHCD compound 3 (Table 1). All three of these compounds showed nanomolar $\sigma_{1} \mathrm{R}$ binding affinity $(\mathrm{K} i=0.067-0.469$ $\mu \mathrm{M})$. The dual and possible multifunctional activity of these compounds justifies further biological evaluation to establish their potential as multifunctional neurotherapeutic agents. A further important consideration when comparing the HCDs affinity to other $\sigma_{1} \mathrm{R}$ ligands is their ability to cross the bloodbrain barrier [34, 35] and other relevant neuroprotective /neurological activities, providing a multitarget-directed drug approach. This study has also shown that the inclusion of an amine heterocycle into these structures could be a viable option in the design of new $\sigma_{1} \mathrm{R}$ ligands with VGCC activity. The reported compounds could prove to be effective lead structures in the development of therapies for the prevention and treatment of neurodegenerative and neurological disorders.

\section{ETHICS APPROVAL AND CONSENT TO PARTI- CIPATE}

Not applicable.

\section{HUMAN AND ANIMAL RIGHTS}

No animals/humans were used for studies that are the basis of this research. 


\section{CONSENT FOR PUBLICATION}

Not applicable.

\section{CONFLICT OF INTEREST}

The authors declare no conflict of interest, financial or otherwise.

\section{ACKNOWLEDGEMENTS}

The authors would like to thank the National Research Foundation and Medical Research Council of South Africa for research funding. The project described was supported by the National Institute Of General Medical Sciences (NIH: NIG MS), U54GM104942. The content is solely the respon-sibility of the authors and does not represent the official views of the funding bodies.

\section{REFERENCES}

[1] Martin, W.R.; Eades, C.G.; Thompson, J.A.; Huppler, R.E.; Gilbert, P.E. The effects of morphine- and nalorphine- like drugs in the nondependent and morphine-dependent chronic spinal dog. $J$. Pharmacol. Exp. Ther., 1976, 197(3), 517-532. [PMID: 945347]

[2] Quirion, R.; Chicheportiche, R.; Contreras, P.; Johnson, K.; Lodge, D.; William Tam, S.; Woods, J.; Zukin, S. Classification and nomenclature of phencyclidine and sigma receptor sites. Trends Neurosci., 1987, 10, 444-446.

[http://dx.doi.org/10.1016/0166-2236(87)90094-4]

[3] Hellewell, S.B.; Bowen, W.D. A sigma-like binding site in rat pheochromocytoma (PC12) cells: Decreased affinity for (+)benzomorphans and lower molecular weight suggest a different sigma receptor form from that of guinea pig brain. Brain Res., 1990, 527(2), 244-253.

[http://dx.doi.org/10.1016/0006-8993(90)91143-5] [PMID: 2174717]

[4] Quirion, W.; Bowen, Y.; Itzhak, J.; Junien, J.; Musacchio, R.; Rothman, S.; Tsung-Ping, S. Tam; Taylor, D. A proposal for the classification of sigma binding sites. Trends Pharmacol. Sci., 1992, $13,85-86$.

[http://dx.doi.org/10.1016/0165-6147(92)90030-A] [PMID: 1315463]

[5] Hanner, F.; Moebius, A.; Flandorfer, H.; Knaus, J.; Striessnig, E. Kempner; Glossmann, H. Purification, molecular cloning, and expression of the mammalian sigma1-binding site. P. Natl. Acad. Sci., 1996, 93, 8072-8077.

[http://dx.doi.org/10.1073/pnas.93.15.8072]

[6] Aydar, E.; Palmer, C.P.; Klyachko, V.A.; Jackson, M.B. The sigma receptor as a ligand-regulated auxiliary potassium channel subunit. Neuron, 2002, 34(3), 399-410.

[http://dx.doi.org/10.1016/S0896-6273(02)00677-3] [PMID: 1198 8171]

[7] Hayashi, T.; Su, T.P. Sigma-1 receptor chaperones at the ERmitochondrion interface regulate $\mathrm{Ca}(2+)$ signaling and cell survival. Cell, 2007, 131(3), 596-610.

[http://dx.doi.org/10.1016/j.cell.2007.08.036] [PMID: 17981125]

[8] Jupp, B.; Lawrence, A.J. New horizons for therapeutics in drug and alcohol abuse. Pharmacol. Ther., 2010, 125(1), 138-168.

[http://dx.doi.org/10.1016/j.pharmthera.2009.11.002] [PMID: 1991 7308]

[9] Rousseaux, C.G.; Greene, S.F. Sigma receptors [ $\sigma$ Rs]: Biology in normal and diseased states. J. Recept. Sig. Transd., 2016, 4(36), 327-388.

[http://dx.doi.org/10.3109/10799893.2015.1015737]

[10] Su, T.P.; Hayashi, T.; Vaupel, D.B. When the endogenous hallucinogenic trace amine N,N-dimethyltryptamine meets the sigma-1 receptor. Sci. Signal., 2009, 2(61), pe12-pe12.

[http://dx.doi.org/10.1126/scisignal.261pe12] [PMID: 19278957]

[11] DeCoster, M.A.; Klette, K.L.; Knight, E.S.; Tortella, F.C. Sigma receptor-mediated neuroprotection against glutamate toxicity in primary rat neuronal cultures. Brain Res., 1995, 671(1), 45-53. [http://dx.doi.org/10.1016/0006-8993(94)01294-R] [PMID: 7728532]

[12] Bowen, W.D. Sigma receptors: recent advances and new clinical potentials. Pharm. Acta Helv., 2000, 74(2-3), 211-218.
[http://dx.doi.org/10.1016/S0031-6865(99)00034-5] [PMID: 1081 2960]

[13] Hayashi, T.; Maurice, T.; Su, T.P. Ca(2+) signaling via sigma(1)receptors: novel regulatory mechanism affecting intracellular $\mathrm{Ca}(2+)$ concentration. J. Pharmacol. Exp. Ther., 2000, 293(3), 788-798. [PMID: 10869377]

[14] MacVicar, T.D.; Mannack, L.V.; Lees, R.M.; Lane, J.D. Targeted siRNA screens identify ER-to-mitochondrial calcium exchange in autophagy and mitophagy responses in RPE1 cells. Int. J. Mol. Sci., 2015, 16(6), 13356-13380.

[http://dx.doi.org/10.3390/ijms160613356] [PMID: 26110381]

[15] Maurice, T.; Su, T.P. The pharmacology of sigma-1 receptors. Pharmacol. Ther., 2009, 124(2), 195-206.

[http://dx.doi.org/10.1016/j.pharmthera.2009.07.001] [PMID: 1961 9582]

[16] Hayashi, T.; Stahl, S. The sigma-1 (delta-1) receptor and its role in the treament of mood disorders. Drugs Future, 2009, 34, 137.

[http://dx.doi.org/10.1358/dof.2009.034.02.1336115]

[17] Tam, S.; Cook, L. Sigma opiates and certain antipsychotic drugs mutually inhibit (+)-[3H] SKF 10,047 and [3H]haloperidol binding in guinea pig brain membranes. P. Natl. Acad. Sci., 1984, 81, 5618-5621. [http://dx.doi.org/10.1073/pnas.81.17.5618]

[18] Itzhak, Y.; Kassim, C.O. Clorgyline displays high affinity for sigma binding sites in C57BL/6 mouse brain. Eur. J. Pharmacol., 1990, 176(1), 107-108.

[http://dx.doi.org/10.1016/0014-2999(90)90139-W] [PMID: 2155796]

[19] Narita, N.; Hashimoto, K.; Tomitaka, S.; Minabe, Y. Interactions of selective serotonin reuptake inhibitors with subtypes of sigma receptors in rat brain. Eur. J. Pharmacol., 1996, 307(1), 117-119. [http://dx.doi.org/10.1016/0014-2999(96)00254-3] [PMID: 8831113]

[20] Maurice, T. Improving Alzheimer's Disease-Related Cognitive Deficits with sigmal Receptor Agonists. Drug News Perspect., 2002, 15(10), 617-625.

[http://dx.doi.org/10.1358/dnp.2002.15.10.740241] [PMID: 12677246]

[21] Kulkarni, S.K.; Dhir, A. sigma-1 receptors in major depression and anxiety. Expert Rev. Neurother., 2009, 9(7), 1021-1034. [http://dx.doi.org/10.1586/ern.09.40] [PMID: 19589051]

[22] J. Pharmacol. Sci., 2005, 97, 317-336. [http://dx.doi.org/10.1254/jphs.CRJ04005X] [PMID: 15750289]

[23] Maurice, T.; Martin-Fardon, R.; Romieu, P.; Matsumoto, R.R. Sigma(1) (sigma(1)) receptor antagonists represent a new strategy against cocaine addiction and toxicity. Neurosci. Biobehav. Rev., 2002, 26(4), 499-527.

[http://dx.doi.org/10.1016/S0149-7634(02)00017-9] [PMID: 1220 4195]

[24] Geldenhuys, W.J.; Malan, S.F.; Bloomquist, J.R.; Marchand, A.P Van der Schyf, C.J. Pharmacology and structure-activity relationships of bioactive polycyclic cage compounds: A focus on pentacycloundecane derivatives. Med. Res. Rev., 2005, 25(1), 21-48. [http://dx.doi.org/10.1002/med.20013] [PMID: 15389731]

[25] Joubert, J.; Geldenhuys, W.J.; Van der Schyf, C.J.; Oliver, D.W.; Kruger, H.G.; Govender, T.; Malan, S.F. Polycyclic cage structures as lipophilic scaffolds for neuroactive drugs. ChemMedChem, 2012, 7(3), 375-384.

[http://dx.doi.org/10.1002/cmdc.201100559] [PMID: 22307951]

[26] Nguyen, V.H.; Kassiou, M.; Johnston, G.A.; Christie, M.J. Comparison of binding parameters of sigma 1 and sigma 2 binding sites in rat and guinea pig brain membranes: novel subtype-selective trishomocubanes. Eur. J. Pharmacol., 1996, 311(2-3), 233-240. [http://dx.doi.org/10.1016/0014-2999(96)00395-0] [PMID: 8891604]

[27] Geldenhuys, W.J.; Malan, S.F.; Bloomquist, J.R.; Van der Schyf, C.J. Structure-activity relationships of pentacycloundecylamines at the Nmethyl-d-aspartate receptor. Bioorg. Med. Chem., 2007, 15(3), $1525-1532$

[http://dx.doi.org/10.1016/j.bmc.2006.09.060] [PMID: 17157509]

[28] Lemmer, H.J.R.; Joubert, J.; van Dyk, S.; van der Westhuizen, F.H.; Malan, S.F. S-nitrosylation and attenuation of excessive calcium flux by pentacycloundecane derivatives. Med. Chem., 2012, 8(3), 361-371. [http://dx.doi.org/10.2174/1573406411208030361] [PMID: 22530904]

[29] Geldenhuys, W.J.; Bezuidenhout, L.M.; Dluzen, D.E. Effects of a novel dopamine uptake inhibitor upon extracellular dopamine from superfused murine striatal tissue. Eur. J. Pharmacol., 2009, 619(1-3), 38-43.

[http://dx.doi.org/10.1016/j.ejphar.2009.08.012] [PMID: 19686731]

[30] Van der Schyf, C.J.; Squier, G.J.; Coetzee, W.A. Characterization of NGP 1-01, an aromatic polycyclic amine, as a calcium antagonist. Pharmacol. Res. Commun., 1986, 18(5), 407-417. 
[http://dx.doi.org/10.1016/0031-6989(86)90162-1] [PMID: 3737654]

[31] Kassiou, M.; Nguyen, V.; Knott, R.; Christie, M.; Hambley, T. Trishomocubanes, a new class of selective and high affinity ligands for the sigma binding site. Bioorg. Med. Chem. Lett., 1996, 6, 595-600. [http://dx.doi.org/10.1016/0960-894X(96)00067-4]

[32] Marrazzo, A.; Prezzavento, O.; Pasquinucci, L.; Vittorio, F.; Ronsisvalle, G. Synthesis and pharmacological evaluation of potent and enantioselective sigma 1, and sigma 2 ligands. Farmaco, 2001, 56(3), 181-189.

[http://dx.doi.org/10.1016/S0014-827X(01)01039-4] [PMID: 1140 9325]

[33] Geldenhuys, W.J.; Novotny, N.; Malan, S.F.; Van der Schyf, C.J. 3DQSAR and docking studies of pentacycloundecylamines at the sigma-1 $(\sigma 1)$ receptor. Bioorg. Med. Chem. Lett., 2013, 23(6), 1707-1711. [http://dx.doi.org/10.1016/j.bmcl.2013.01.069] [PMID: 23414839]

[34] Zah, J.; Terre'Blanche, G.; Erasmus, E.; Malan, S. Physicochemical prediction of a brain-blood distribution profile in polycyclic amines. Bioorg. Med. Chem., 2003, 11, 3569-3578.

[http://dx.doi.org/10.1016/S0968-0896(03)00365-1] [PMID: 1290 1901]

[35] Prins, L.H.; du Preez, J.L.; van Dyk, S.; Malan, S.F. Polycyclic cage structures as carrier molecules for neuroprotective non-steroidal antiinflammatory drugs. Eur. J. Med. Chem., 2009, 44(6), 2577-2582. [http://dx.doi.org/10.1016/j.ejmech.2009.01.030] [PMID: 19233517]

[36] Ablordeppey, S.Y.; Fischer, J.B.; Glennon, R.A. Is a nitrogen atom an important pharmacophoric element in sigma ligand binding? Bioorg. Med. Chem., 2000, 8(8), 2105-2111.

[http://dx.doi.org/10.1016/S0968-0896(00)00148-6] [PMID: 1100 3156]

[37] Ablordeppey, S.Y.; Fischer, J.B.; Law, H.; Glennon, R.A. Probing the proposed phenyl-A region of the sigma-1 receptor. Bioorg. Med. Chem., 2002, 10(8), 2759-2765.

[http://dx.doi.org/10.1016/S0968-0896(02)00096-2] [PMID: 1205 7665]

[38] Joubert, J.; Sharma, R.; Onani, M.; Malan, S. Microwave-assisted

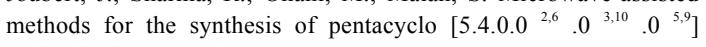
undecylamines Tetrahedron Lett., 2013, 54, 6923-6927.

[http://dx.doi.org/10.1016/j.tetlet.2013.10.047]

[39] Banister, S.D.; Moussa, I.A.; Jordan, M.J.; Coster, M.J.; Kassiou, M. Oxo-bridged isomers of aza-trishomocubane sigma (sigma) receptor ligands: Synthesis, in vitro binding, and molecular modeling. Bioorg. Med. Chem. Lett., 2010, 20(1), 145-148.

[http://dx.doi.org/10.1016/j.bmcl.2009.11.019] [PMID: 19954972]

[40] Buschauer, A.; Postius, S.; Szelenyi, I.; Schunack, W. Isohistamine and homologs as components of H2-antagonists. 22. H2antihistaminics. Arzneimittelforschung, 1985, 35(7), 1025-1029. [PMID: 2864932]

[41] Matsumoto, R.R.; Bowen, W.D.; Tom, M.A.; Vo, V.N.; Truong, D.D.; De Costa, B.R. Characterization of two novel sigma receptor ligands: antidystonic effects in rats suggest sigma receptor antagonism. Eur. J. Pharmacol., 1995, 280(3), 301-310.

[http://dx.doi.org/10.1016/0014-2999(95)00208-3] [PMID: 8566098]

[42] Glennon, R.A.; Ablordeppey, S.Y.; Ismaiel, A.M.; el-Ashmawy, M.B.; Fischer, J.B.; Howie, K.B. Structural features important for sigma 1 receptor binding. J. Med. Chem., 1994, 37(8), 1214-1219. [http://dx.doi.org/10.1021/jm00034a020] [PMID: 8164264]

[43] Schmidt, H.R.; Zheng, S.; Gurpinar, E.; Koehl, A.; Manglik, A.; Kruse, A.C. Crystal structure of the human $\sigma 1$ receptor. Nature, 2016, 532(7600), 527-530

[http://dx.doi.org/10.1038/nature17391] [PMID: 27042935]

[44] Zindo, F.T.; Barber, Q.R.; Joubert, J.; Bergh, J.J.; Petzer, J.P.; Malan, S.F. Polycyclic propargylamine and acetylene derivatives as multifunctional neuroprotective agents. Eur. J. Med. Chem., 2014, 80, 122-134.

[http://dx.doi.org/10.1016/j.ejmech.2014.04.039] [PMID: 24769350]

[45] Hollingsworth, E.B.; McNeal, E.T.; Burton, J.L.; Williams, R.J.; Daly, J.W.; Creveling, C.R. Biochemical characterization of a filtered synaptoneurosome preparation from guinea pig cerebral cortex: cyclic adenosine $3^{\prime}: 5^{\prime}$-monophosphate-generating systems, receptors, and enzymes. J. Neurosci., 1985, 5(8), 2240-2253.

[http://dx.doi.org/10.1523/JNEUROSCI.05-08-02240.1985] [PMID: 2991484]

[46] Peeters, M.; Romieu, P.; Maurice, T.; Su, T.P.; Maloteaux, J.M.; Hermans, E. Involvement of the sigma 1 receptor in the modulation of dopaminergic transmission by amantadine. Eur. J. Neurosci., 2004, 19(8), 2212-2220

[http://dx.doi.org/10.1111/j.0953-816X.2004.03297.x] [PMID: 1509 0047]

[47] Banister, S.D.; Moussa, I.A.; Jordan, M.J.T.; Coster, M.J.; Kassiou, M. Oxo-bridged isomers of aza-trishomocubane sigma (sigma) receptor ligands: Synthesis, in vitro binding, and molecular modeling. Bioorg. Med. Chem. Lett., 2010, 20(1), 145-148.

[http://dx.doi.org/10.1016/j.bmcl.2009.11.019] [PMID: 19954972]

[48] Cookson, R.; Hill, R.; Hudec, J. The stereochemistry of the adducts of $p$-benzoquinone with two molecules of cyclopentadiene. Chargetransfer from olefinic double bonds to $p$-benzoquinone and ene-1,4dione groups J. Chem. Soc., 1964, 3043.

[http://dx.doi.org/10.1039/jr9640003043]

[49] Binda, C.; Li, M.; Hubalek, F.; Restelli, N.; Edmondson, D.E.; Mattevi, A. Insights into the mode of inhibition of human mitochondrial monoamine oxidase B from high-resolution crystal structures. Proc. Natl. Acad. Sci. USA, 2003, 100(17), 9750-9755. [http://dx.doi.org/10.1073/pnas.1633804100] [PMID: 12913124]

[50] Boström, J.; Greenwood, J.R.; Gottfries, J. Assessing the performance of OMEGA with respect to retrieving bioactive conformations. J. Mol. Graph. Model., 2003, 21(5), 449-462.

[http://dx.doi.org/10.1016/S1093-3263(02)00204-8] [PMID: 1254 3140]

(C) 2019 Joubert et al.

This is an open access article distributed under the terms of the Creative Commons Attribution 4.0 International Public License (CC-BY 4.0), a copy of which is available at: (https://creativecommons.org/licenses/by/4.0/legalcode). This license permits unrestricted use, distribution, and reproduction in any medium, provided the original author and source are credited. 